\title{
Ionic Currents of Kenyon Cells from the Mushroom Body of the Honeybee
}

\author{
Sabine Schäfer, Hendrik Rosenboom, and Randolf Menzel \\ Institut für Neurobiologie, der Freien Universität, 14195 Berlin, Germany
}

The mushroom bodies have been suggested to be essentially involved in learning and memory in insects. In the honeybee Apis mellifera they are composed of about 340,000 intrinsic elements, called Kenyon cells, which can be easily separated from all other neurons of the brain. Here we describe a preparation in which we studied ionic currents in the isolated Kenyon cell somata, using tight-seal whole-cell recording. Several outward and inward currents were identified and investigated by the use of pharmacological agents and in ion substitution experiments: a rapidly inactivating A-type potassium current that is completely blocked with 5 mu 4-aminopyridine; a calcium-activated potassium current that is blocked by 1-100 nM charybdotoxin; a delayed rectifier-type potassium current that is only weakly sensitive to tetraethylammonium but is blocked by $100 \mu \mathrm{M}$ quinidine; a rapidly activating and inactivating, TTX-sensitive sodium current; a persistent sodium current that is both TTX and cadmium sensitive; and a calcium current that is completely blocked at $\mathbf{5 0} \mu \mathrm{m}$ cadmium and is affected by verapamil and nifedipine only at high concentrations $(100 \mu \mathrm{M})$. The currents described here are very similar to currents found in other insect neurons or muscle cells.

This preparation will not only facilitate studies concerning the action of transmitters and neuromodulators that are contained within neurons converging onto the Kenyon cells, but will also allow a study of the role of the adenylyl cyclase pathway, elements of which are expressed in Kenyon cells, and are known to be essential for learning in invertebrates.

[Key words: insect, whole-cell patch clamp, potassium currents, sodium currents, calcium currents]

The mushroom bodies are probably the most peculiar structures in the insect brain, which has encouraged wide speculations about their possible function. Evidence for an involvement in learning and memory was initially derived from studies in the honeybee, which showed that selectively disturbing mushroom body function by cooling causes retrograde amnesia aftcr olfactory training (Menzel et al., 1974; Masuhr, 1976; Erber et al., 1980). Behavioral analysis of Drosophila mutants defective in

\footnotetext{
Received Sept. 13, 1993; revised Dec. 29, 1993; accepted Jan. 13, 1994

We thank Sabine Kreissl for introducing us to the cell preparation, Gerd Bicker for sharing the cell culture facilities with us, Christine Jaeckel and Sybille Schaare for technical assistance, and Paul Stevenson and Martin Hammer for comments on the manuscript. We are especially grateful to Tomaz Amon for assistance and a good spirit during the final phase of the experiments. This work was supported by DFG Grant Pf 128/6-3 (S.S.) and a Leibniz award (R.M.).

Correspondence should be addressed to Dr. Sabine Schäfer, Institut für Neurobiologie, Königin-Luise-Strasse 28/30, 14195 Berlin, Germany.

Copyright (C) 1994 Society for Neuroscience $0270-6474 / 94 / 144600-13 \$ 05.00 / 0$
}

mushroom body structure revealed that the mutants behave poorly in olfactory conditioning tasks compared to wild-type animals (Heisenberg et al., 1985). The gene products of Drosophila learning mutants dunce (dnc) and rutabaga (rut) have been shown to be preferentially expressed in the intrinsic elements of the mushroom bodies, the Kenyon cells (Nighorn et al., 1991; Han et al., 1992; see Davis, 1993, for review). Both mutations interfere with the cAMP pathway by affecting a cAMPspecific phosphodiesterase and a calcium/calmodulin-responsive adenylyl cyclase, respectively (Byers et al., 1981; Livingstone et al., 1984). Behavioral pharmacological experiments with honeybees revealed that octopamine injected into the mushroom bodies facilitates olfactory learning and memory retrieval (Bicker and Menzel, 1989; Menzel ct al., 1990), and biochemical studies indicate that the cAMP cascade may be involved in mediating this effect (Menzel et al., 1991). In an electrophysiological study, a presumably octopaminergic neuron has been identified, which projects into the main input region of the bee mushroom bodies, the calyces, and mediates the reward in olfactory learning (Hammer, 1993). Furthermore, Mauelshagen (1993) demonstrated changes in the response of an identified mushroom body extrinsic neuron to an odorant after applying a classical olfactory conditioning paradigm. Taken together, these results provide evidence for an important role of the mushroom body intrinsic elements, the Kenyon cells, in olfactory learning and memory.

Unfortunately, due to the small size of cell bodies and processes in flies and bees, electrophysiological investigations on the Kenyon cells cannot be performed in vivo. We therefore decided to study the isolated Kenyon cell somata of honeybee pupae using tight-seal whole-cell recording (Hamill et al., 1981). This technique is particularly suitable for small cells and has already been successfully applied to a variety of insect neuronal preparations (Byerly and Leung, 1988; O'Dowd and Aldrich, 1988; Solc and Aldrich, 1988; Hardie and Weckström, 1990; Hardie, 1991; Saito and Wu, 1991; Laurent et al., 1993; Pearson ct al., 1993). Anatomical studies in the honeybee revealed that each mushroom body contains about 170,000 Kenyon cells as the only intrinsic neuronal type (Witthöft, 1967; Mobbs, 1982). Because of their morphology, the mushroom bodies in this insect can easily be dissected out of the brain (Fig. 1) and their subsequent dissociation yields a pure preparation of Kenyon cells.

With this article we give a description of the variety of voltagegated and calcium-activated currents that are present in the isolated somata of pupal Kenyon cells. The currents are compared to those found in other insect neuronal and muscle preparations. Since we were the first to do voltage-clamp studies with these neurons, we started to characterize their whole-cell 

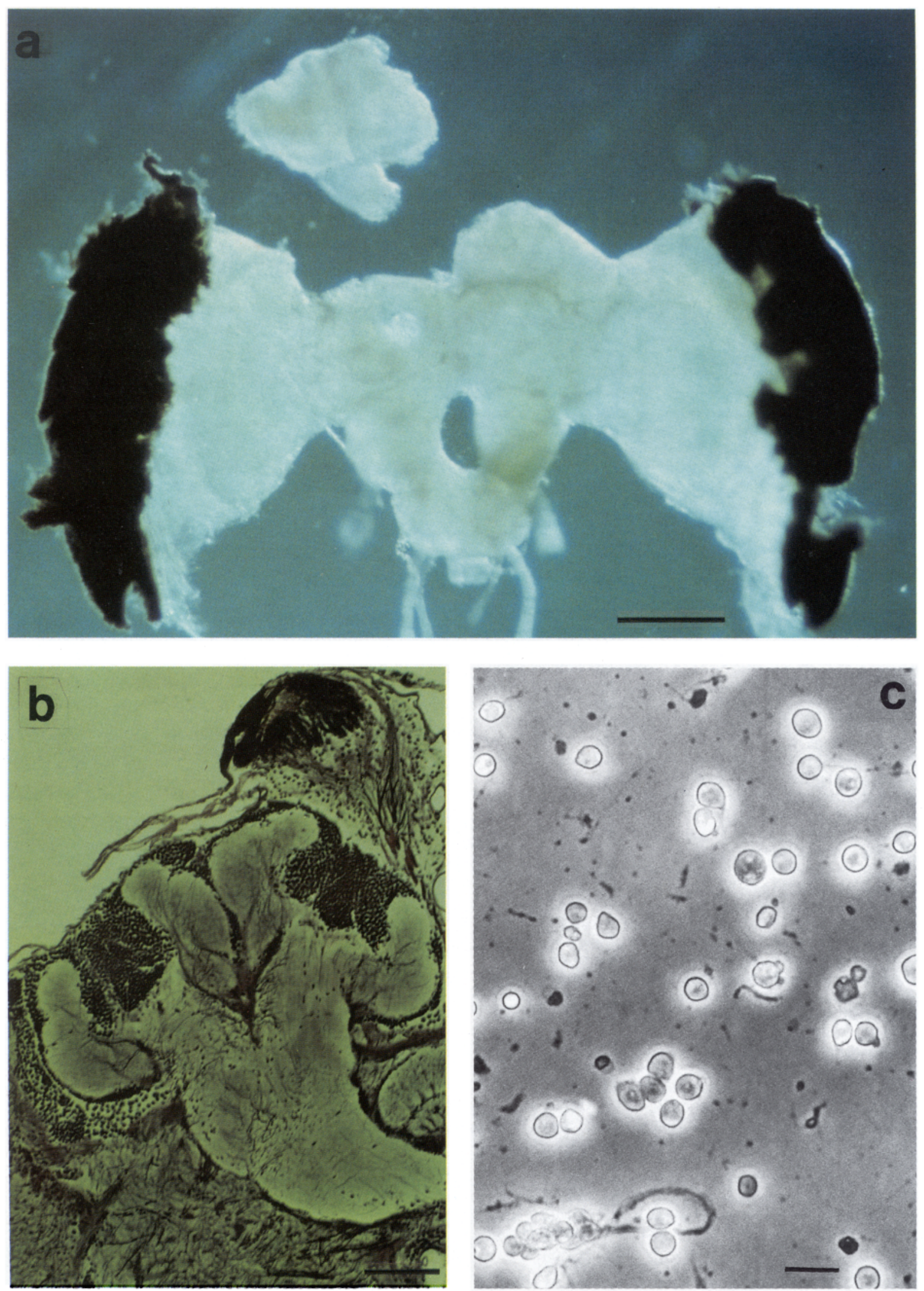

Figure 1. The mushroom body and its intrinsic neurons. A, Pupal brain with the left mushroom body dissected out of the brain and the right one still in place within the dorsal protocerebrum. $B$, Bodian-stained frontal section through the mushroom body, showing the somata of Kenyon cells located within two cup-shaped structures, the calyces. This picture illustrates how well the cell bodies of the Kenyon cells are separated from the somata of other neurons of the protocerebrum. $C$, Isolated somata of Kenyon cells viewed under phase contrast. Scale bars: $a, 500 \mu \mathrm{m} ; b, 100$ $\mu \mathrm{m} ; c, 20 \mu \mathrm{m}$. 
currents. The results provide the basis for future investigations on the action of transmitter substances and neuromodulators that, with immunocytochemical techniques, have been shown to be contained within neurons converging onto the Kenyon cells. Since the dnc and rit gene products have been shown to be present in Kenyon cells, we are particularly interested in a possible involvement of the adenylyl cyclase pathway in modulating ionic currents of these cells.

A preliminary report of some of the work presented here has appeared in abstract form (Schäfer et al., 1993).

\section{Materials and Methods}

Animals. Honeybee (Apis mellifera) pupae were collected from the comb between days 2 and 6 of the pupal development, which lasts $9 \mathrm{~d}$ under natural conditions. They were reared at $28^{\circ} \mathrm{C}$ and $80 \%$ relative humidity in an incubator until they had reached $70-80 \%$ of adult development (i.c.. pupal day 7) judged on the basis of the body pigmentation.

Cell preparation. Kenyon cells of 7-d-old pupae were dissected and cultured following the protocol of Kreissl (1992: Kreissl and Bicker, 1992) with only minor modifications. In brief, brains were removed from the head capsule in a Leibovit\% L 15 medium (GIBCO Bethesda Research Laboratory) supplemented with sucrose, glucose, fructose, and proline $(42.0,4.0,2.5$, and $3.3 \mathrm{gm} / 500 \mathrm{ml}$, respectively) to reach a final osmolarity of $500 \mathrm{mOsm}$ (L15-500). After the brains had been exposed to a hyperosmolar medium (containing $59 \mathrm{gm}$ instead of $42 \mathrm{gm}$ sucrose/ $500 \mathrm{ml}: 600 \mathrm{mOsm}$ ), the glial sheath could be removed readily. This was followed by another step in L15-500 medium in which mushroom bodies were dissected out of the brains. After a $10 \mathrm{~min}$ incubation in a calcium-free Ringer solution (in mm: $130 \mathrm{NaCl}, 5 \mathrm{KCl}, 10 \mathrm{MgCl}_{2}, 25$ glucose, 180 sucrose, 10 HEPES; pH 7.2), mushroom bodies (MBs) were transferred back to $\mathrm{L} 15-500$ medium $(4 \mathrm{MBs} / 200 \mu \mathrm{l})$ and finally dissociated by gentle trituration with a $100 \mu \mathrm{l}$ siliconized Eppendorf pipette. Cells were then plated in $25 \mu$ aliquots into $100 \mu \mathrm{l}$ droplets of L15-500 medium on uncoated Falcon plastic dishes and allowed to attach for at Icast $15 \mathrm{~min}$. Thereafter, the dishes were filled with $2.5 \mathrm{ml}$ of L $15-500$ and were kept at $29^{\circ} \mathrm{C}$ in an incubator at high humidity. Under these conditions the cells can survive for up to $10 \mathrm{~d}$ in culture (Kreissl, 1992).

Electrophysiological techniques. Whole-cell gigaohm seal recording was performed at room temperature following the methods described by Hamill et al. (1981). Recordings were made using a Axopatch 1D amplifier (Axon Instruments). Pulse generation, data acquisition, and analysis were carried out using a TL- 1 interface in conjunction with pCLAMP programs (Axon instruments) running on an AT-type microcomputer. Pipette and membrane capacitance were compensated, and series resistance compensation $(80 \%)$ was routinely employed. Currents were low-pass filtered with a 4-pole Bessel filter at 2-5 kHz and digitally sampled at 4-20 $\mathrm{kHz}$, depending on the current under investigation. Voltages were corrected for liquid junction potential; leakage currents were not subtracted. Electrodes were pulled from borosilicate glass capillaries (GC 150-15, Clark, Reading) and had tip resistances between 4 and $6 \mathrm{M} \Omega$ in standard external solution (see below). For statistical analysis of the data we used ORIGIN (MicroCal Inc.). Where appropriate, data are presented as mean \pm standard error of the mean (SEM), unless stated otherwise.

Solutions. The bath was continuously perfused at $2 \mathrm{ml} / \mathrm{min}$ with a standard external solution that consisted of (in mм) $130 \mathrm{NaCl}, 6 \mathrm{KCl}$, $4 \mathrm{MgCl}_{2}, 5 \mathrm{CaCl}_{2}, 160$ sucrose, 25 glucose, $10 \mathrm{HFPFS} / \mathrm{NaOH} ; \mathrm{pH} 7.2$. In some experiments $\mathrm{Ca}^{2} \cdot$ was replaced by $\mathrm{Ba}^{2}$. For the analysis of outward currents $200 \mathrm{nM}$ tetrodotoxin (TTX) and in some cases $50 \mu \mathrm{M}$ $\mathrm{CdCl}_{2}$ was added. The standard internal solution contained (in mM): $100 \mathrm{~K}$-aspartate, $40 \mathrm{KF}, 20 \mathrm{KCl}, 2.5 \mathrm{MgCl}_{2}, 1$ EGTA, $3 \mathrm{ATP}, 160$ sucrose. 10 HEPES; $\mathrm{pH}$ 7.2. For the recording of inward currents $\mathrm{KCl}$ was replaced by TEA-Cl and the remaining $\mathrm{K}$ was substituted by $\mathrm{Cs}$. Totally synthetic, HPLC-purified charybdotoxin was obtained from Bachem (Heidelberg. Germany). All other chemicals were purchased from Sigma (St. Louis, MO).

\section{Results}

Based on the size of their cell bodies, two subtypes of Kenyon cells can be distinguished: one $10 \mu \mathrm{m}$, the other $7 \mu \mathrm{m}$ in diameter (Fig. 1b,c). While the larger cell bodies are already present in the larval and carly pupal stages, the smaller-diameter somata appear not before the second half of pupal development, after neurogenesis of Kenyon cells has been completed. Judged by their location in the center of the calycal cups, the $7 \mu \mathrm{m}$ cells are most likely the latest progeny of Kenyon cell neuroblasts ( $\mathrm{S}$. Eichmüller and S. Schäfer, unpublished observations). In contrast to Kenyon cells of younger pupae, which in the dish usually grow a single long and thin process within a few hours after dissociation, the cells of late-stage pupae used in the present study hardly differentiate within the first $2 \mathrm{~d}$. Recordings were made only from $10 \mu \mathrm{m}$ cells without processes, $12-36 \mathrm{hr}$ after dissociation. The membrane capacitance estimated from the capacitance compensation settings on the amplifier was $2.6 \pm$ $0.5 \mathrm{pF}$ (mean $\pm \mathrm{SD} ; n=91)$ and did not change with the time the cells had spent in culture. As the cells did not show any inward rectifying potassium currents, or any other gated currents at voltages below $-60 \mathrm{mV}$. their input resistance was determined cither from the slope of the current-voltage relationship between -60 and $-120 \mathrm{mV}$, or. simply, by calculation from the response to a step to $-90 \mathrm{mV}$ from a holding potential of $-60 \mathrm{mV}$. The input resistance was $6.6 \pm 3.3 \mathrm{G} \Omega$ (mean $\pm \mathrm{SD}$; $n=31$ ). With the exception of a transient sodium current, which could not be detected during the first $18 \mathrm{hr}$, all of the other currents described below were also seen in cells that were studied immediately after dissociation $(n=8)$. However, with these cells it was extremely difficult to obtain a whole-cell configuration.

In response to depolarizing voltage steps from a holding potential of $-65 \mathrm{mV}$ the cells showed a fast and transient inward current followed by a much larger outward current (Fig. 2). Both inward and outward currents are a combination of scveral components that can be separated by the use of pharmacological iools and the application of appropriate pulse protocols.

\section{Outward currents}

The outward current is composed of a rapidly inactivating and a noninactivating phase. In most of the cells examined, the $I-$ I' curve for the outward current had a characteristic $\mathrm{N}$-shape with a halfway peak around $+50 \mathrm{mV}$ (Fig. 2, inset). Alterations in the external $\mathrm{K}^{+}$concentration and measurements of tailcurrent reversal potentials indicate that the outward current is primarily carricd by $\mathrm{K}^{+}$(not shown). Further analysis, performed in the presence of $200 \mathrm{nM}$ TTX in the external solution to block $\mathrm{Na}^{+}$currents, revealed that the outward current is composed of at least three different potassium currents.

Calcium-activated $K^{+}$currents. Eliminating calcium currents by addition of $50 \mu \mathrm{M}$ cadmium to the bath solution dramatically altered the size and shape of the outward current: both transient and sustained phase were considerably reduced in size, and the inactivation of the transient component became faster. Furthermore, the $\mathrm{N}$-shape of the $I-V$ relation was completely abolished (Fig. 3). Switching to an external solution containing 2 mm cobalt or exposure to a calcium-free saline had the same effect. As these observations are indicative for the presence of a calcium-activated potassium conductance, we tested whether charybdotoxin (ChTX), a blocker for a subtype of calcium-activated potassium channels. also changes size and shape of the outward current. Indeed, ChTX (1-100 nm) blocked a transient outward current that activates at potentials above $-30 \mathrm{mV}$ and has a maximum around $+50 \mathrm{mV}$ (Fig. 4). Since the current gradually decreased with time and repeated application of depolarizing pulse protocols, its block by ChTX could be shown 


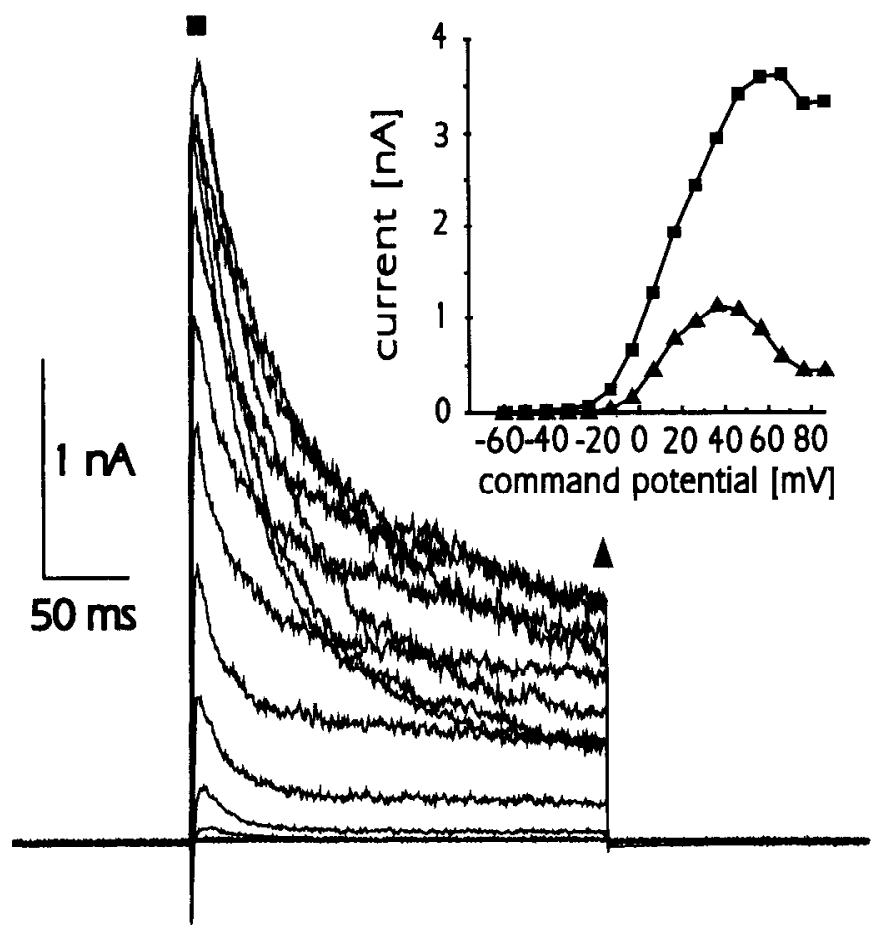

Figure 2. Whole-cell current in the absence of any blocking agents. The membrane potential was stepped from a holding potential of -65 $\mathrm{mV}$ to a prepulse potential of $-95 \mathrm{mV}$ for $100 \mathrm{msec}$ and then depolarized for $250 \mathrm{msec}$ to command potentials between -65 and $+85 \mathrm{mV}$ in $10 \mathrm{mV}$ increments. Voltage steps were applied every $5 \mathrm{sec}$. The $I-V$ curves for the peak outward ( $\boldsymbol{\square})$ and sustained outward current $(\boldsymbol{\Delta})$ are shown in the inset.

to be reversible only for a few cells in which it was exceptionally large at the very beginning. In addition to this transient current, ChTX in some cells also affected a small, sustained component of thc outward current (Fig. $4 d, e$ ) that, in contrast to the transient calcium-activated potassium current, continuously increased with increasing depolarization. As its time course resembled the delayed rectifier-type current described below, this component of the ChTX-sensitive outward current may be due to an unspecific action of the toxin.

A-type current. Superfusing the cells with an external solution containing TTX, $\mathrm{CdCl}_{2}$, and quinidine (200 nM, $50 \mu \mathrm{M}$, and 100 $\mu \mathrm{M}$, respectively) revealed a very rapidly activating and inactivating outward current (Fig. 5). The time course and sensitivity to 4-aminopyridine (4-AP; Fig. 6) indicate this to be an A-type current (Rudy, 1988). The block is voltage independent since 4-AP reduced the current by the same percentage over a large voltage range. To reveal the dose-response relationship we applied activation pulse protocols before and in the presence of three different concentrations of $4-A P(0.2,1$, and $5 \mathrm{~mm})$. The rclative current persisting at a given concentration was expressed as the mean of the values determined for five consecutive voltage steps (to $10,25,40,55$, and $70 \mathrm{mV}$ ). The inset of Figure 6 shows that the block is half-maximal at $0.8 \mathrm{~mm}$, and is nearly complete at $5 \mathrm{~mm}$ 4-AP.

Voltage activation curves were determined by measuring the peak current activated by a given voltage (Fig. $7 a, b$ ). From these values the conductance $(g)$ was calculated, using the relationship

$$
g=I /(E-V) \text {. }
$$

For $E$ we used the potassium equilibrium potential $(-85 \mathrm{mV})$

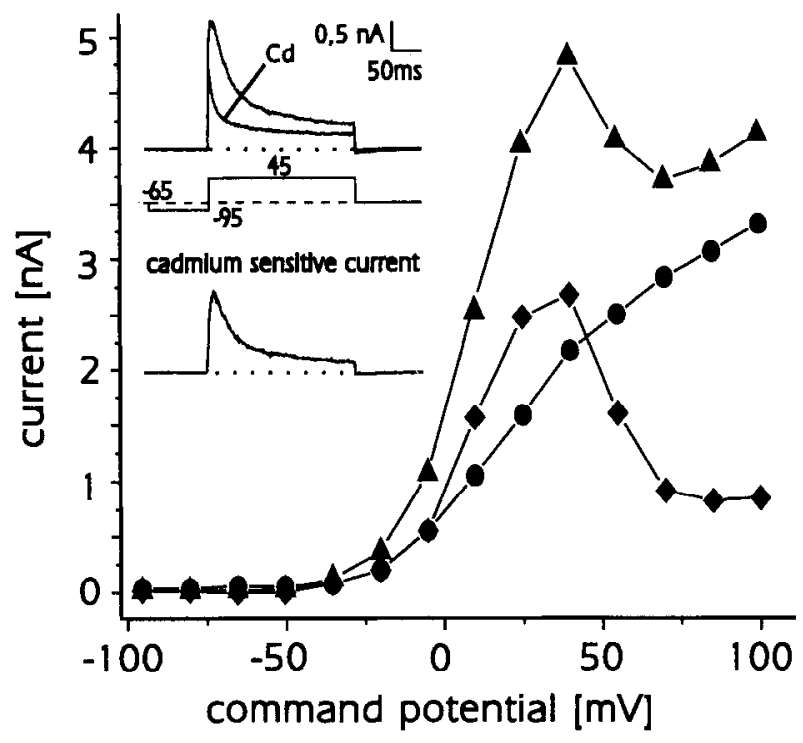

Figure 3. Effect of $50 \mu \mathrm{M}$ cadmium on the outward current in the presence of $100 \mathrm{~nm}$ TTX. $I-V$ curves for the peak outward current before ( $\Delta$ ) and after $(\boldsymbol{\theta})$ cadmium. $\rightarrow$ indicate the $I-V$ relation of the cadmium-sensitive current obtained after subtracting the traces obtained in the presence from those before cadmium. The inset shows the response to a step to $+45 \mathrm{mV}$.

determined according to the Nernst equation, assuming the potassium concentration within the cell to be identical to that of the pipette filling solution. Even though the absolute size of the A-type current was different from cell to cell (Fig. 7b), the respective curves for the relationship between the fraction of conductance activated $\left(g / g_{\text {max }}\right)$ and voltage were almost identical. From the normalized $g-V$ curves a mean was calculated and fitted (Fig. $7 c$ ) with a Boltzmann distribution of the form

$$
g / g_{\max }=1 /\left\{1+\exp \left[\left(V-V_{1 / 2}\right) / S\right]\right\},
$$

where $V_{1,2}$ is the voltage at which half of the current is activated and $S$ is a factor determining the slope of the curve. The resulting values were $+10.7 \mathrm{mV}\left(V_{1 / 2}\right)$ and $-16.76(S)$. Steady state inactivation curves were obtained by measuring the peak current in response to a test pulse $(+30 \mathrm{mV})$ from different preconditioning voltages (Fig. $7 d, e$ ). The mean inactivation curve and its Boltzmann fit are shown in Figure $7 f$. The $V_{1 / 2}$ and $S$ values resulting from the fit were $-42.33 \mathrm{mV}$ and 8.15 , respectively. For a description of the kinetics of the current we measured time to peak for the activation, and examined the decay of the current by fitting a single exponential to the falling phase at each voltage. The time to peak ranged from $5-23 \mathrm{msec}$ near threshold to about $2 \mathrm{msec}$ at $+40 \mathrm{mV}$ and above. The first-order time constant for the inactivation was $1-4 \mathrm{msec}$ above $+40 \mathrm{mV}$.

Delayed-rectifier current. Elimination of the A-type current by depolarizing prepulses to $-25 \mathrm{mV}$ uncovered a third type of outward current (Fig. 8) that slowly activates with depolar-

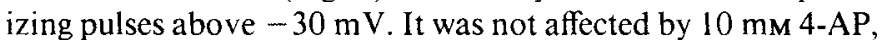
a concentration at which the A-type current was blocked completely. The effect of externally applied tetraethylammonium (TEA) was somewhat variable: in some cells the current was reduced only slightly by $20 \mathrm{~mm}$ TEA, and could not bc completely blocked even at a concentration of $100 \mathrm{~mm}$; in other cases $20 \mathrm{~mm}$ TEA reduced the current to one-fourth or onefifth of the original size. In general, the sensitivity to TEA was 

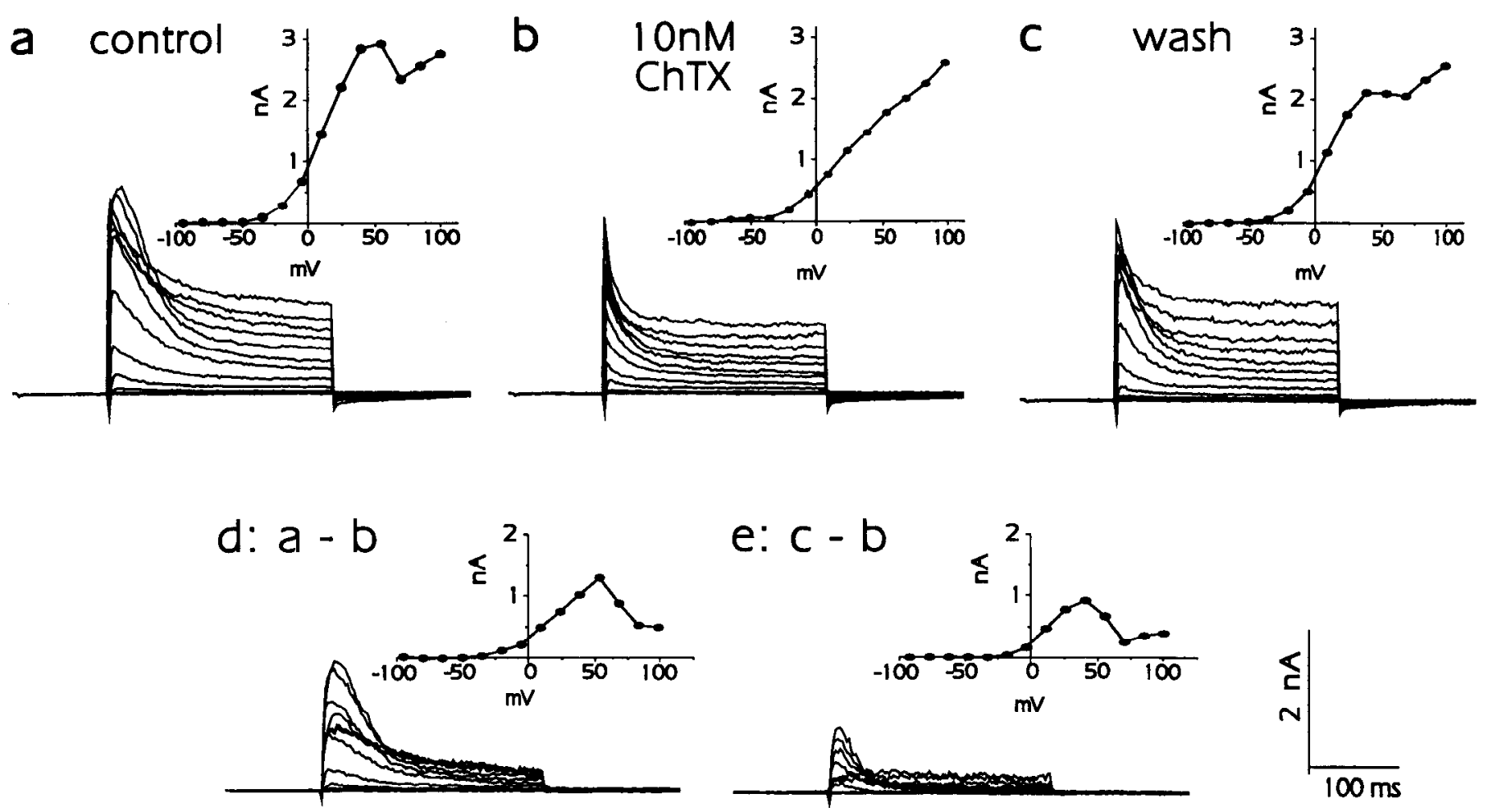

Figure 4. Effect of charybdotoxin $(C h T X)$ on outward currents. The insets show the $I-V$ curvcs for the pcak outward current. The cell was held at $-65 \mathrm{mV}$, and after a $100 \mathrm{msec}$ hyperpolarizing prepulse to $-95 \mathrm{mV}$ it was depolarized for $250 \mathrm{msec}$ to command potentials between -80 and $100 \mathrm{mV}$, in $15 \mathrm{mV}$ increments. $a$, Before application of ChTX the peak outward current has a maximum at $+55 \mathrm{mV}$. $b$, In the presence of ChTX the peak outward current becomes apparently more transient and its $I-V$ curve looses the typical N-shape. $c$, The effect is partially reversed after a 2 min wash. $d$ and $e$, The time course of the ChTX-sensitive current obtained by subtracting $b$ from $a(d)$, and $b$ from $c(e)$.

related to the size of the current: the larger the current before application, the stronger the TEA effect. On the basis of its relatively slow activation, and because it showed only little inactivation even with depolarizations lasting as long as $2 \mathrm{sec}$, we have classified it as a delayed rectifier-type current. Since we observed some variability in the activation speed and inactivation of the current, we believe that there are at least two subtypes of channels with different activation and inactivation kinetics underlying the total current. However, as we were not able to separate these components of the current any further, we have not analyzed its kinetics in detail. Like its counterparts in other insect preparations (Singh and Wu, 1990; Hardie, 1991), it is sensitive to quinidine, being completely abolished with 100 $\mu \mathrm{M}$ (Fig. 5). In contrast to the A-type current, which persisted without change in recording sessions of over $30 \mathrm{~min}$, the delayed rectifier-type current showed massive rundown already within the first $2 \mathrm{~min}$ after establishing the whole-cell configuration. Whether this reflects the existence of another subtype of delayed rectifier-type channel, which may require intracellular conditions that cannot be maintained during whole-cell recording, remains to be seen.

\section{Inward currents}

For an analysis of the inward current, outward currents were blocked by substituting $\mathrm{KCl}$ with $\mathrm{TEA}-\mathrm{Cl}$ and $\mathrm{KF}$ with $\mathrm{CsF}$ in the pipette solution. Under these conditions the remaining whole-
Figure 5. Effect of quinidine on outward currents. Same pulse protocol as in Figure 4. Quinidine significantly reduces a sustained outward current component and leaves the very rapidly inactivating outward current largely unaffected. Inward currents and calcium-activated outward currents were blocked with $100 \mathrm{nM}$ TTX and $50 \mu \mathrm{M}$ cadmium.

\section{$+50 \mu \mathrm{M}$ Quinidine}




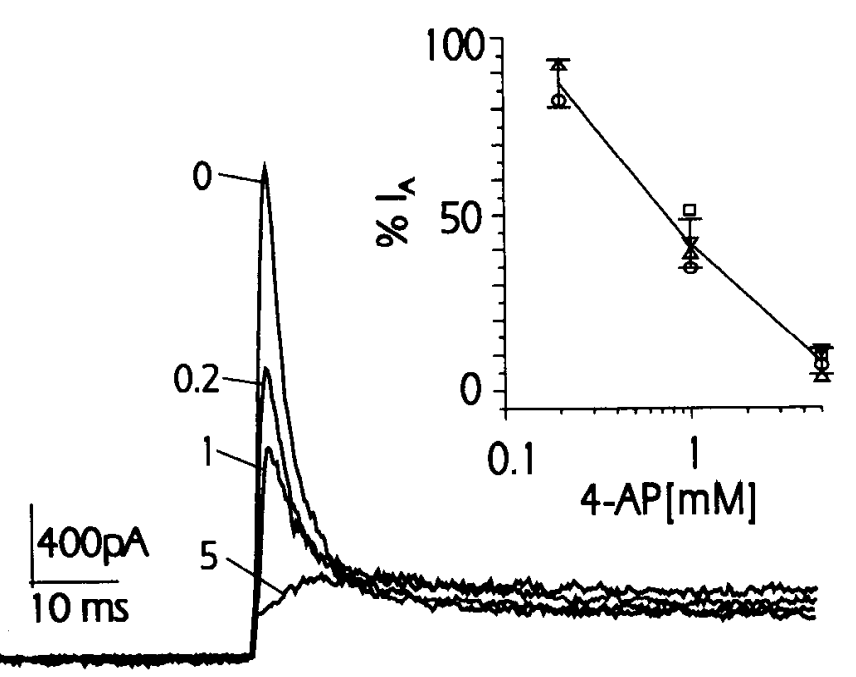

Figure 6. 4-Aminopyridine sensitivity of the A-type current. The current was elicited by a step to $+40 \mathrm{mV}$ following a hyperpolarizing prepulse to $-95 \mathrm{mV}$ from a holding potential of $-65 \mathrm{mV}$. It was recorded in the presence of TTX, Cd, and quinidine to block all other currents. The concentrations of 4-AP tested were $0.2,1$, and $5 \mathrm{~mm}$. The inset shows the dose-response relation obtained from three different cells.

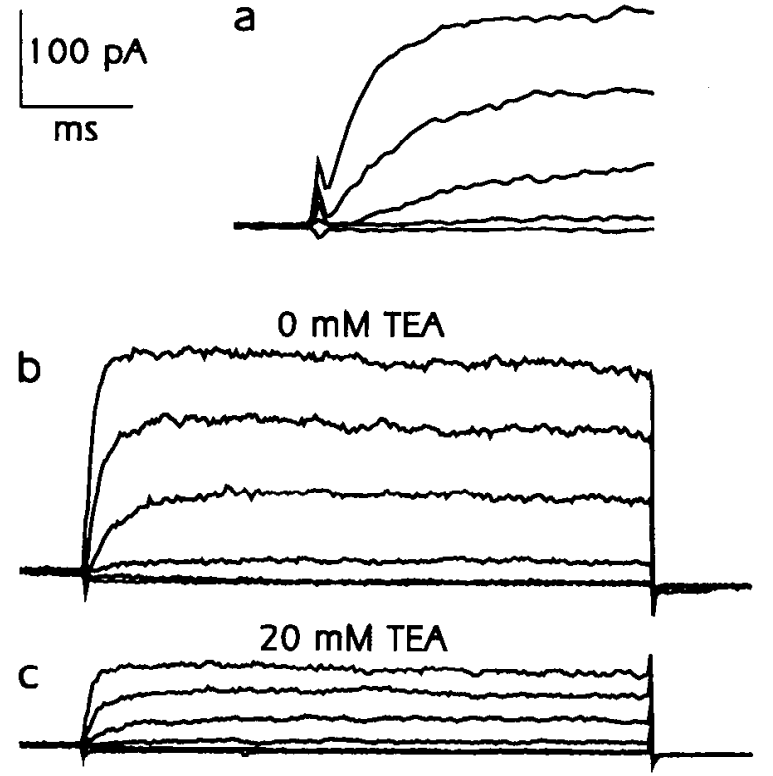

Figure 8. Delayed rectifier-type outward current and its partial block by TEA. The current was recorded in the presence of $100 \mathrm{nM}$ TTX and $50 \mu \mathrm{M} \mathrm{Cd}$. The A-type current was totally inactivated by a $200 \mathrm{msec}$ depolarizing prepulse to $-25 \mathrm{mV}$. Test pulses to $-50,-35,-20,-5$, and $+10 \mathrm{mV}$. $a$ and $b$ show the same traces with different sweep speed. $c$, In this example $20 \mathrm{~mm}$ TEA reduced the current to $40 \%$ of its original size. Time scale: $a, 8 \mathrm{msec} ; b$ and $c, 50 \mathrm{msec}$.
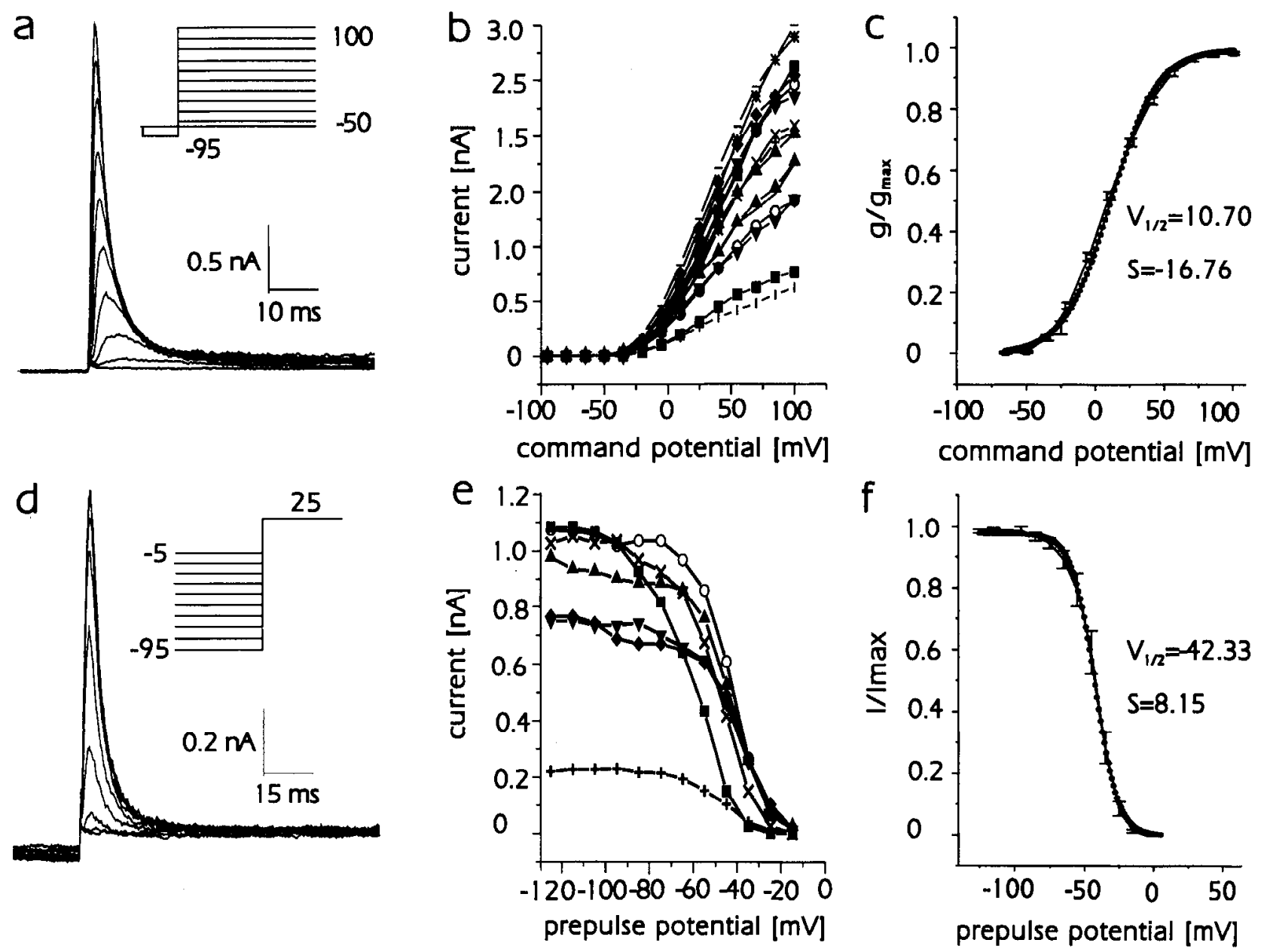

Figure 7. Characterization of the A-type current. The current was isolated by application of $100 \mathrm{nM}$ TTX, $50 \mu \mathrm{M} \mathrm{Cd,} \mathrm{and} 50 \mu \mathrm{M}$ quinidine. $a-c$, Activation of the A-type current. Same pulse protocol as in Figure $4 . d-f$. Steady state inactivation determined by applying preconditioning voltage pulses between -115 and $+5 \mathrm{mV}$ that preceded a test pulse to $+25 \mathrm{mV}$. For further description, see Results. 


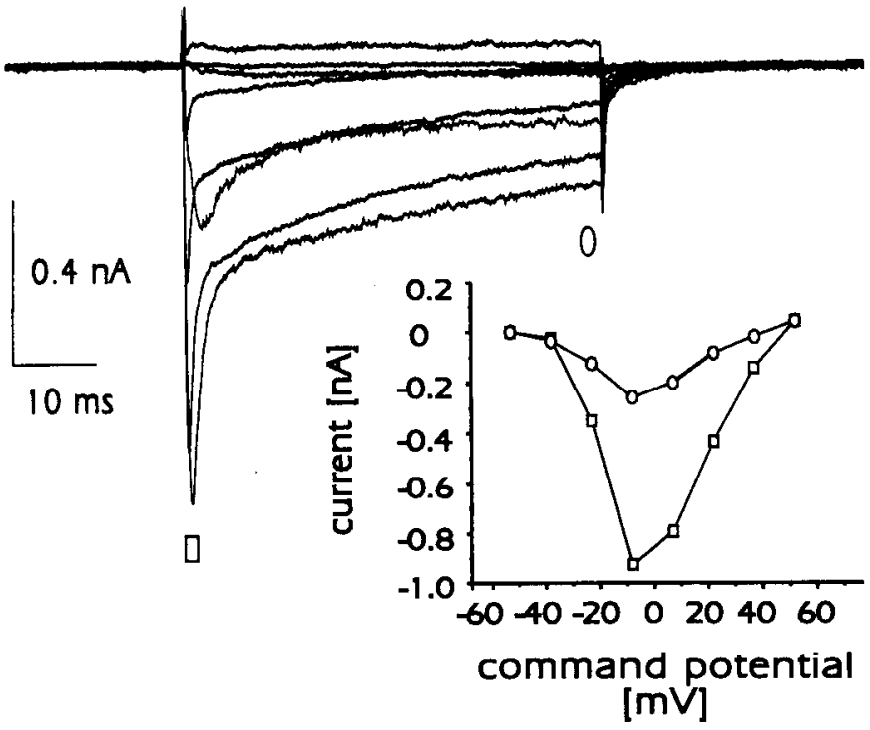

Figure 9. Total inward current. The pipette was filled with $\mathrm{CsCl}$ and TEA to block potassium currents. The inward current has at least two components: one activating and inactivating rapidly, and one that decays more slowly. The inset shows the $I-V$ curves for the peak $(\square)$ and the late (O) inward current. cell current was mainly inward and showed a transient and a more slowly inactivating component (Fig. 9), the latter of which is normally masked by the massive outward currents. Both components are first activated by pulses to $40 \mathrm{mV}$ and peak near $-10 \mathrm{mV}$. They can be separated pharmacologically and in ion substitution experiments.

Sodium currents. Since we expected some of the inward current to be carried by calcium, we blocked calcium currents with $50 \mu \mathbf{M}$ cadmium to study sodium currents in isolation. Under these conditions only a transient inward current remained, which was completely blocked with 50-100 nM TTX (see Fig. 11b) and disappeared in $\mathrm{Na}^{+}$-free external solution, indicating that this component of the inward current was indeed a sodium current. Of all the currents examined, this current was the only one for which we noticed an obvious correlation between the size of the current and the time the cells had spent in vitro after dissociation: during the first $18 \mathrm{hr}$ the current could not be detected at all and thereafter seemingly increased with the time the cells had been in culture. Since we restricted our investigations to cells that had not developed any processes, the appearance of the transient sodium current does not seem to require any morphological differentiation.

Figure $10 a-c$ shows an example of this inward sodium current and the $I-V$ relation for 14 measurements. The current is activated at command potentials more positive than $-45 \mathrm{mV}$ a
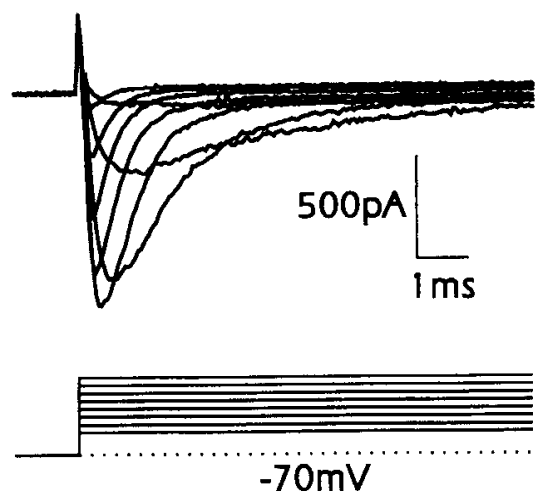

$-70 \mathrm{mV}$
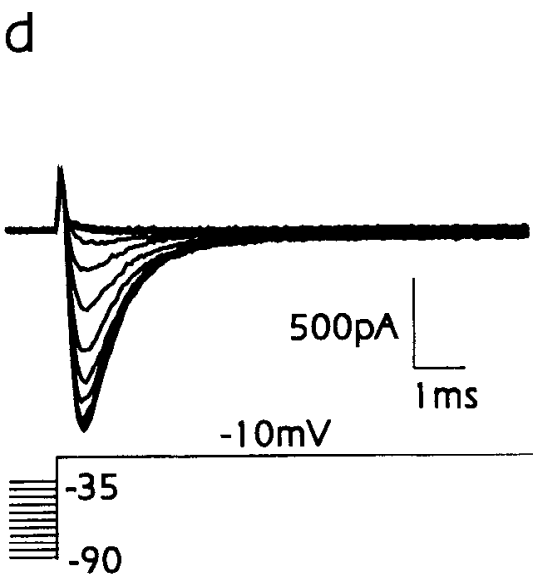

b

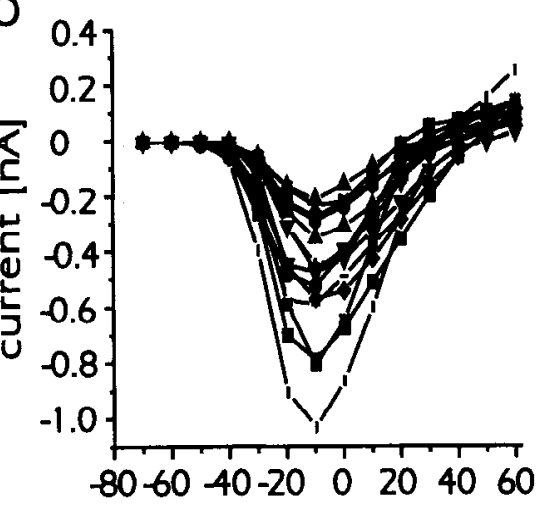

command potential [mV]

e

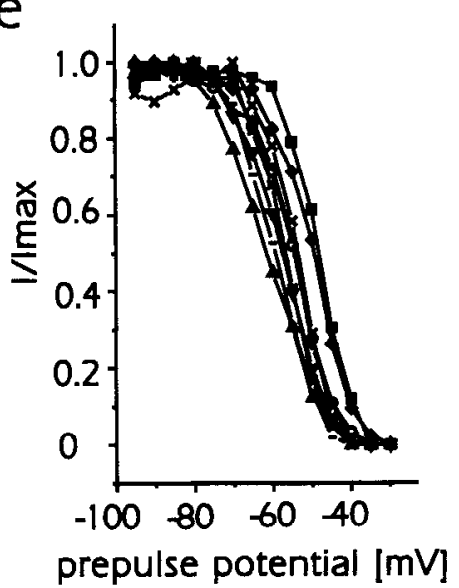

C

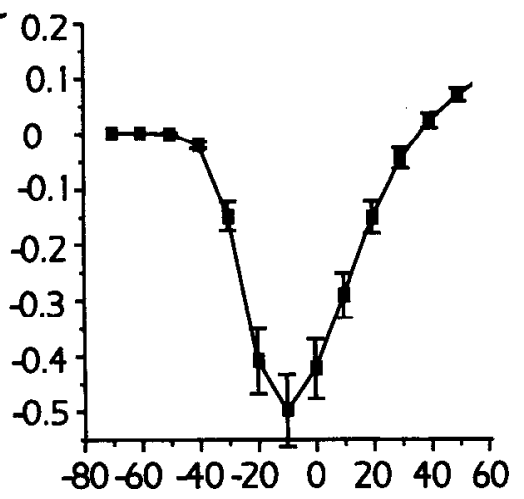

f

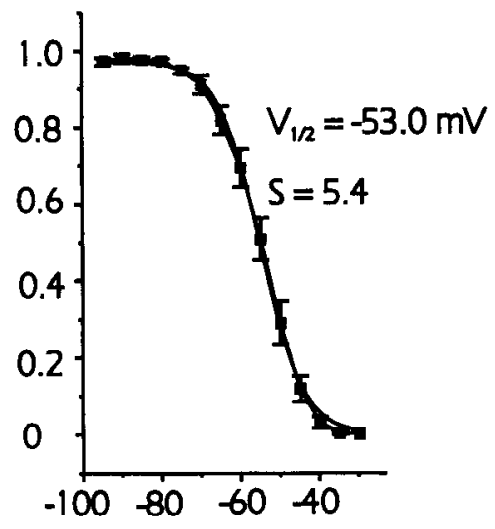

Figure 10. Transient sodium currents recorded in the presence of $50 \mu \mathrm{M} C d$ to block calcium currents. $a-c$, To measure the activation of the current, cells were held at $-70 \mathrm{mV}$ and depolarized to command potentials between -60 and $+60 \mathrm{mV}$, in $10 \mathrm{mV}$ increments. $d-f$, Steady state inactivation determined by application of preconditioning voltage pulses between -95 and $-30 \mathrm{mV}$, in $5 \mathrm{mV}$ increments, followed by a test pulse to $-10 \mathrm{mV}$. For further information, see Results. 
a
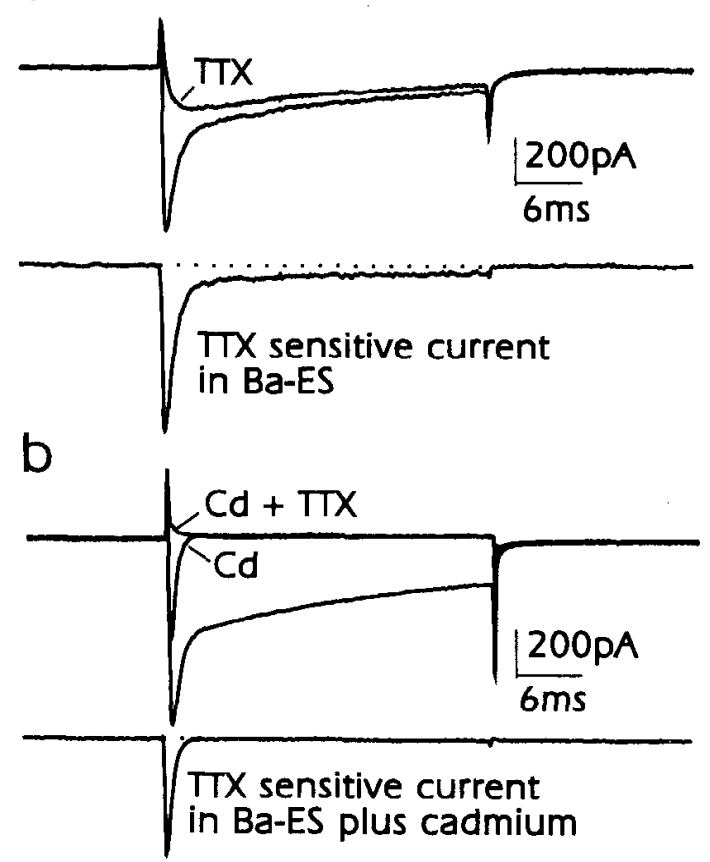

Figure 11. Effect of 100 nм TTX on the inward current. Barium was substituted for calcium in the external solution. Both $a$ and $b$ show the response to a test pulse to $-10 \mathrm{mV}$ from a holding potential of -70 $\mathrm{mV}$. a, Application of TTX blocks an inward current that has a transient and a persistent component (lower trace). $b$, After application of cadmium only a transient inward current, which is blocked by TTX (lower trace), is observed. with a maximum around $-10 \mathrm{mV}$. With more positive test pulses the current decreases as the potential approaches the sodium equilibrium potential $(+55 \mathrm{mV})$. Since we did not routinely use leak subtraction protocols, the sodium current is opposed by leakage and incompletely compensated capacitive currents, both of which are outward at the command potentials applied. Therefore, the reversal potential of the current differed from cell to cell, and deviated from the sodium equilibrium potential, especially when the sodium current was relatively small. In a few cases we did apply on-line leak subtraction using a $P / N$ protocol, resulting in $I-V$ curves that reversed very close to the sodium equilibrium. Neither activation threshold nor voltage at which the current was maximal differed from the values given above. Steady state inactivation was examined by applying $1 \mathrm{sec}$ prepulses to voltages between -95 and $-30 \mathrm{mV}$ in $5 \mathrm{mV}$ increments (Fig. 10d,e). From a set of nine normalized inactivation curves $\left(I / I_{\max }\right)$, the mean was calculated and fitted (Fig. 10f) with a Boltzmann distribution (Eq. 2) giving a $V_{1 / 2}$ of $-53 \mathrm{mV}$ and a slope factor $S$ of 5.4 .

The time course of the sodium current was characterized by measuring time to peak $\left(t_{\mathrm{p}}\right)$ and inactivation rate. For the average of 14 cells measured, $t_{\mu}$ decreased from $2.8 \pm 0.3$ at -40 $\mathrm{mV}$ to $0.3 \pm 0.02$ at $+30 \mathrm{mV}$. The inactivation time constant $\left(t_{\mathrm{h}}\right)$ was determined from the fit of a single exponential to the falling phase of the sodium current. It decreased with potential from $3.7 \pm 0.4$ at $-40 \mathrm{mV}$ to $0.3 \pm 0.05$ at $+30 \mathrm{mV}$.

Without $\mathrm{Cd}$ in the bath, application of TTX not only abolished the transient sodium current, but also eliminated a sustained component of the inward current (Fig. $11 a$ ). Superfusing the cells with an $\mathrm{Na}^{+}$-free solution had the same effect, indicating the existence of a persistent sodium current in addition to the transient sodium current described above. Since we never a

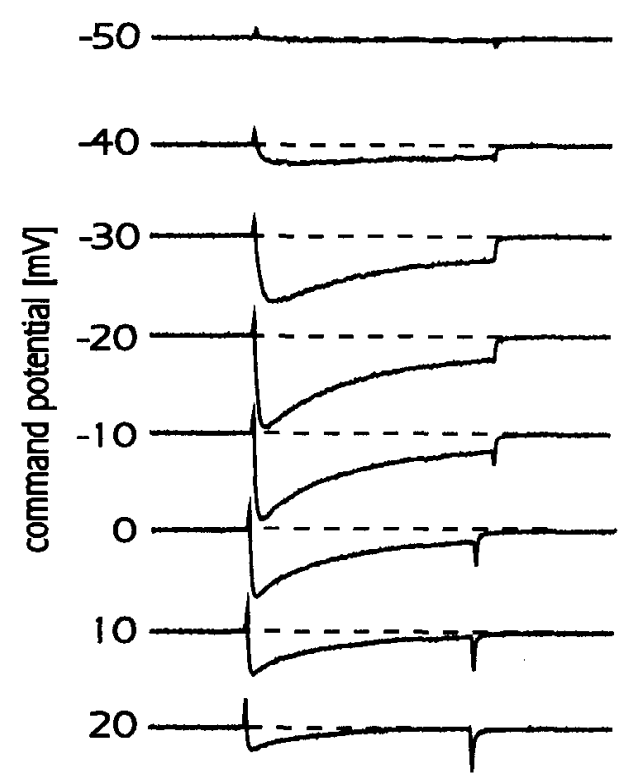

b

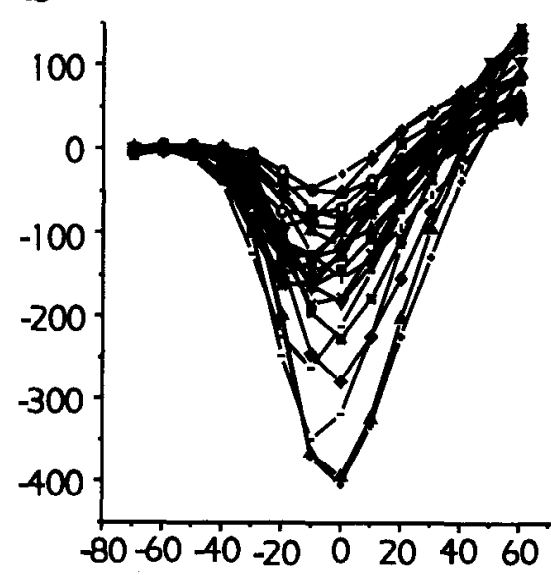

command potential [mV]
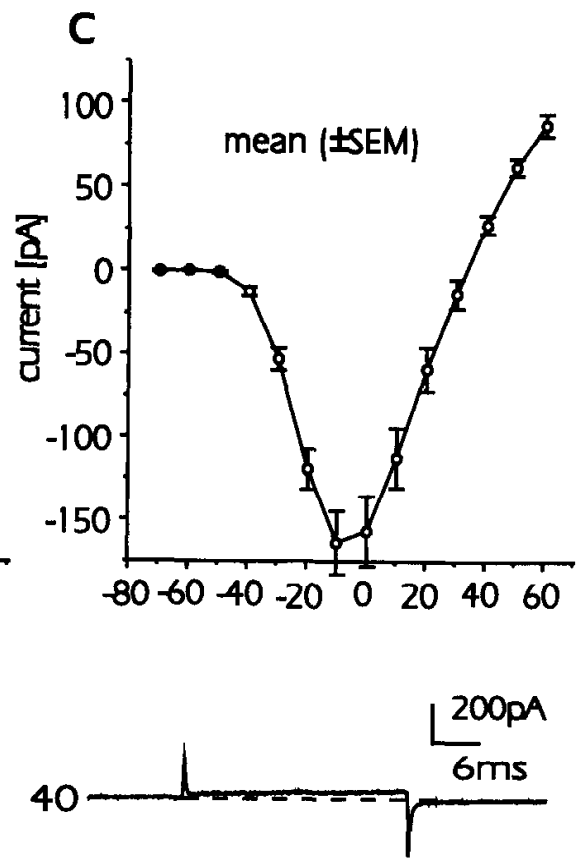

Figure 12. Barium currents recorded in the presence of $100 \mathrm{nM}$ TTX to block sodium currents. Cells were held at $-70 \mathrm{mV}$ and depolarized to. command potentials between 0 and $+60 \mathrm{mV}$, in $10 \mathrm{mV}$ increments. $b, I-V$ curves for the peak barium current obtained from 20 different cells. $c$, Mean barium current activation curve $( \pm \mathrm{SEM})$. 
Figure 13. Effect of calcium channel blockers on the barium current. The same cell was consecutively exposed to verapamil $(100 \mu \mathbf{M} ; a)$, cadmium $(10$ $\mu \mathbf{M} ; b)$, and nifedipine $(100 \mu \mathrm{M} ; c)$ with a 5 min wash between the applications. Upper traces show the response to a depolarizing pulse to $-10 \mathrm{mV}$ (holding potential $-70 \mathrm{mV}$ ) before and after application of the drug. Iower traces were obtained after subtraction, and depict the time course of the verapamil-, cadmium-, and nifedipine-sensitive current, respectively.
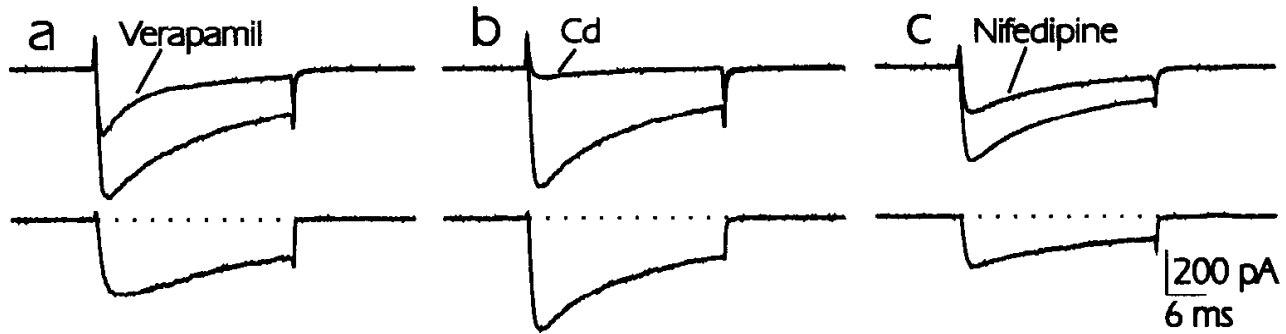

observed a persistent component of the inward current in 50 $\mu \mathrm{M}$ Cd (Fig. $11 b$ ), this persistent sodium current could either be $\mathrm{Cd}$ sensitive or require calcium influx into the cell for its activation.

Calcium current. In an external solution containing $200 \mathrm{~nm}$ TTX, an inward current was observed that activates and inactivates more slowly than the transient sodium current. It was completely blocked by $50 \mu \mathbf{M}$ cadmium (Fig. 11b) and also disappeared when calcium in the external solution was removed or replaced by cobalt (not shown). We therefore regard this current to be a calcium current.

With calcium as a charge carrier, the current rapidly decreased to one-half to one-fifth of its original size within a few minutes. When calcium was substituted by barium this rundown was much less pronounced, suggesting that the calcium current may be inactivated or regulated in a calcium-dependent manner. However, this process must be fairly slow since the inactivation kinetics, as judged from the $50 \mathrm{msec}$ pulses, were not obviously altered after switching to a barium-containing external solution. Replacing calcium with barium also resulted in an instantaneous increase of the current without a change in the reversal potential, indicating that the calcium channels underlying the whole-cell current are more permeable to barium than to calcium.

Figure 12 gives an example of the barium current and shows the $I-V$ relations for the peak current derived from 20 different cells from a holding potential of $-70 \mathrm{mV}$. An average ( \pm SEM) of all 20 measurements is shown in Figure $12 c$. The current is first activated at $-40 \mathrm{mV}$ and peaks between -10 and $0 \mathrm{mV}$. Changing the holding potential to more negative valucs increased the current significantly. The barium current was maximal at $-100 \mathrm{mV}$, reduced to three-fourths to two-thirds at -70 $\mathrm{mV}$, and was fully inactivated at $-30 \mathrm{mV}$. Lowering the holding potential to $-100 \mathrm{mV}$ did not uncover a second type of calcium (or barium) current. It simply increased the size of the overall current without affecting its kinetics or the shape of the $I-V$ relation.

For a further pharmacological characterization we studied the effects of organic calcium channel blockers verapamil (a phenylalkylamine) and nifedipine (a dihydropyridine), both of which, in the $20 \mathrm{nM}$ to $50 \mu \mathrm{M}$ range, are thought to select for the L-type calcium channel in vertebrates (Tsien et al., 1988; Hille, 1992). At $100 \mu \mathrm{M}$, verapamil significantly reduced (by $50-90 \%$ ) the barium current in every cell tested ( $n=14$; see Fig. $13 a$ for an example). The effect of $100 \mu \mathrm{M}$ nifedipine (Fig. 13c) was less pronounced (up to $50 \%$ ); in several cases no effect was observed at all. Since we did not try any concentrations other than 100 $\mu \mathrm{M}$ we do not know whether this is due to a difference in the dose-response relationships of the two compounds. A compar- ison of the $I-V$ curves of the nifedipine-sensitive current with that of the current that persisted in nifedipine did not reveal any difference with respect to the voltage at which the current activated, and where the current had its maximum. Furthermore, multiplying the current persisting in nifedipine with a variable factor would give a current with a time course that was more or less identical to that of the current before the application of the drug. Thus, it seems unlikely that there are two different calcium currents, one of which is blocked by nifedipine and one of which is not.

\section{Discussion}

Recordings were performed on Kenyon cell somata isolated from the brain of honeybee pupae that had nearly completed adult development. Using the same dissection and culturing protocol, Kreissl (1992) showed that by injection of depolarizing current the cells can be induced to spike. As the pupal cells do not noticeably differ from adult Kenyon cells in their composition of ionic currents (unpublished observations), we believe that the complement of ion channels expressed in Kenyon cells is complete at the end of the pupal stage. The inward and outward currents observed are similar to those described in other insect neuronal (Byerly and Leung, 1988; Solc and Aldrich, 1988; Baker and Salkoff, 1990; Saito and $\mathrm{Wu}, 1991)$ or muscle preparations (Gho and Mallart, 1986; Zagotta et al., 1988; Singh and $\mathrm{Wu}, 1989,1990)$. In contrast to the former, which included a variety of different cell types dissociated from entire brains or ganglia, the preparation introduced here allows the selective study of a distinct ncuronal population. Investigations were restricted to cells that had not grown any processes during their short-term culture lasting up to $2 \mathrm{~d}$. Even though the pupal Kenyon cell somata have roughly the same diameter and wholecell capacitance as Drosophila embryonic neurons (Byerly and Leung, 1988; O'Dowd and Aldrich, 1988), their currents are about one order of magnitude larger. This may be because we studied a very special neuronal type, or, more likely, because embryonic neurons express fewer ionic channels than pupal neurons. With the Kenyon cell preparation this question may be addressed, because it allows investigation of the expression of ionic currents in this particular neuronal population not only in the late pupa, but also at earlier stages of postembryonic development, and in the adult.

In Drosophila muscle two types of calcium-activated potassium currents have been described: a fast transient current $\left(I_{\mathrm{CF}}\right.$ or $I_{\mathrm{ACD}}$ ) and a slow noninactivating current ( $I_{\mathrm{CS}}$ or $I_{\mathrm{C}}$ ) (Salkoff, 1983; Elkins et al., 1986; Gho and Mallart, 1986; Singh and $\mathrm{Wu}, 1989$ ). Neither one appeared to be affected by apamin, a bee venom polypeptide (Gho and Mallart, 1986) that has been 
shown to block selectively a special type of calcium-activated potassium channel (see Cook and Quast, 1990, for review). $I_{C F}$ has been reported to be blocked by charybdotoxin, a peptide from scorpion venom (Elkins et al., 1986). Because of its time course and its sensitivity to charybdotoxin, the transient calcium-activated current described here closely resembles $I_{\mathrm{CF}}$.

The sustained component of the ChTX-sensitive current seen in Figure 4 may be due to an unspecific block of some other outward current. In contrast to the transient ChTX-sensitive current, the $I-V$ relation of which has an $\mathrm{N}$-shape characteristic for calcium-dependent currents, the $I-V$ curve for the sustaincd component is more or less linear. In some cells ChTX has been reported not to be perfectly selective, affecting not only calciumactivated potassium channels but also delayed rectifier currents (Cook and Quast, 1990). This may also be the case in our preparation.

In addition, Kenyon cells may possess a slow, noninactivating calcium-activated potassium current: in many cells the $I-V$ relation for the persistent component of the outward current also had a characteristic N-shape (Fig. 1). However, this component of the sustained outward current, and hence the N-shape of its $I-V$ curve, usually disappeared within a few minutes after establishing the whole-cell configuration (see, e.g., Fig. 4). Therefore, we were not able to characterize this current further. Recently, Wegener et al. (1992) described a calcium-dependent potassium channel in antennal receptor neurons of the locust that is inhibited by millimolar concentrations of intracellular ATP and is blocked neither by apamin nor by charybdotoxin. As our pipette solution contained $3 \mathrm{~mm}$ ATP, inhibition by ATP of a calcium-activated potassium current would explain the rundown of a sustained outward current with $\mathrm{N}$-shaped $I-$ $V$ relation. So far, we have not performed any experiments without ATP in the pipette solution in order to see whether under such conditions this particular component of the outward current would be more stable.

In an immunological study Schwarz et al. (1990) showed that Drosophila mushroom bodies express high levels of Shakerencoded potassium channels. Thus, it was not surprising for us to find a prominent A-type current in honeybee Kenyon cells that resembles the A-current of Drosophila muscle encoded by the Shaker potassium channel gene, with respect to both its kinetic parameters and its voltage operating range (Salkoff and Wyman, 1983; Wu and Haughland, 1985; Zagotta and Aldrich, 1990). This is not the case in most other insect neuronal preparations in which the operating range of this current appears to be shifted by about $30 \mathrm{mV}$ negative compared to that in Drosophila muscle (Solc and Aldrich, 1988; Hardie and Weckström, 1990; Hardie, 1991; Hardie et al., 1991; Saito and Wu, 1991). It remains to be seen whether the A-type current found in Kenyon cells differs with respect to its voltage operating range from that of other neurons in the bee brain.

In pupal Drosophila neurons Baker and Salkoff (1990) reported a considerable variation in the inactivation kinetics and voltage dependence of the A-type current, and suggested that in some cells two populations of channels coexist. The shape of some of the inactivation curves (e.g., solid diamonds in Fig. 7e) is indeed suggestive of the presence of a second type of A-type current with a more negative voltage operating range. Further experiments are necessary to substantiate this impression.

The second type of voltage-activated outward current encountered in our preparation is characterized by a slow activation, only little inactivation during $250 \mathrm{msec}$ depolarizing pulses, and sensitivity to TEA. It is very similar to the delayed rectifier current found in other insect neurons (Byerly and Leung, 1988; Solc and Aldrich, 1988; Hardie and Weckström, 1990; Hardie, 1991; Saito and $\mathrm{Wu}, 1991$ ). The variability of its activation rate and the degree of inactivation observed during 250 msec test pulses suggest that this current is composed of at least two kinetically different conductances. Several potassium channels have been described that may contribute to sustained outward currents in insect neuronal and muscle preparations (Solc and Aldrich, 1988; Zagotta et al., 1988; Gorczyca and Wu, 1991; Hardic, 1991). In the absence of single-channel data it is difficult to decide which and how many types of channels underlie the delayed rectifier-type current in Kenyon cells. As the current showed only little inactivation during $2 \mathrm{sec}$ voltage steps, a noninactivating potassium channel $\left(\mathrm{K}_{\mathrm{I}}\right.$ or $\left.\mathrm{K}_{\mathrm{O}}\right)$, in addition to the slowly inactivating $\mathrm{K}_{\mathrm{D}}$, must significantly contribute to this current.

The most striking feature of the delayed rectifier-type current was its susceptibility to washout, which occurred within a few minutes after establishing the whole-cell configuration. The fraction of the current that persisted beyond this time was usually stable for the rest of the recording session. This observation, and the variability in the sensitivity of the current to TEA, could be explained with the presence of two subtypes of delayed rectifier channels, one of which is more sensitive to TEA and is readily "washed out," the other being only weakly sensitive to TE $\Lambda$, but resistant to washout. Wc have recently started to apply the perforated-patch technique to our cells using Amphotericin $B$ as an ionophore. Under these conditions the delayed rectifiertype current was stable for a much longer period. Further experiments must now be performed to characterize the current in greater detail.

The transient sodium current described here is virtually indistinguishable, in terms of voltage operating range and kinetic parameters, from that of Drosophila embryonic neurons (O'Dowd and Aldrich, 1988). Since we studied only cells without any apparent processes, the source of the current is obviously the soma membrane. The fact that the sodium current does not arise in neurites (which might have been very thin and therefore overlooked) can also be seen in the current records: we never observed a significant delay between the onset of the test pulse and rising phase of the sodium current, which should occur, if there was improper voltage control over processcs.

It is unlikely that Kenyon cell somata generate sodium-driven action potentials in vivo, as is the case for the majority of insect nerve cell bodies. We observed no sodium currents immediately after dissociation and up to $18 \mathrm{hr}$ thereafter. The same occurs with isolated adult DUM neurons, where the development of the transient sodium current, following axotomy and deafferentation, can be abolished by protein synthesis inhibitors (Tribut et al., 1991). Immunocytochemical studies indicate that sodium channels in insect neurons are primarily located in axon membranes, but restricted to the cytoplasm in cell bodies (French et al., 1993). Our observations suggest that isolated Kenyon cells retain their ability to synthesize sodium channels, which are, however, incorporated into the soma membrane in the absence of an axon. In contrast to the transient sodium current, all other currents described here did not change with time after dissociation. We thus conclude that the channels underlying these currents are also present and functional in Kenyon cell somata in vivo.

Persistent, TTX-sensitive sodium currents have been found 
in cockroach (Christensen et al., 1988; Lapied et al., 1989) and Drosophila (Saito and $\mathrm{Wu}, 1991$ ) neurons. A similar current also seems to be present in Kenyon cells. However, we were not able to study this current in detail, since it could not be effectively separated from the other inward currents. The persistent sodium current was absent when the bath contained micromolar concentrations of cadmium to block the calcium current; substituting calcium by cobalt had the same effect. Isolating both sodium currents together by the use of a calcium-free external solution was also impracticable, as recordings were instable under these conditions. Therefore, we do not know whether the persistent sodium current differs with respect to activation threshold and steady state inactivation from the transient sodium current, as is the case in Drosophila neurons (Saito and Wu, 1991).

Calcium currents have been described in Drosophila embryonic neurons (Byerly and Leung, 1988; Leung and Byerly, 1991; Saito and Wu, 1991), Manduca larval and pupal motoneurons (Hayashi and Levine, 1992), and locust adult (Pearson et al., 1993) and embryonic interneurons (Laurent ct al., 1993). In Drosophila, calcium currents with different inactivation kinetics have been observed (Byerly and Leung, 1988; Saito and Wu, 1991), which were differentially affected by two spider toxins, indicating the existence of two different types of neuronal calcium currents (Leung et al., 1989). In contrast, the waveform of the calcium current described here was rather consistent from cell to cell, presumably because we recorded only from Kenyon cells, and not from a variety of different neuronal types. Laurent et al. (1993) made a similar observation studying calcium currents in nonspiking interneurons from the locust.

Substituting calcium with barium had two effects. First, it increased the current without changing the reversal potential, indicating that the underlying calcium channels, like those present in adult locust neurons (Pearson et al., 1993), are more permeable to barium than to calcium. Second, it very much slowed the rundown of the current, which would normally result in a loss of the calcium current within 5-10 min, possibly because of a calcium-dependent inactivation or regulation of the current. Barium, however, could not reverse rundown once it had occurred. Unlike Drosophila embryonic neurons (Saito and $\mathrm{Wu}, 1991$ ), barium did not change the waveform of the current, indicating that the inactivation observed during $50 \mathrm{msec}$ depolarizing pulses is most likely not calcium dependent, and that the calcium-dependent regulation of the calcium current leading to rundown must be a rather slow process.

Organic calcium channel blockers, such as verapamil and nifedipine, which block certain types of vertebrate calcium channels, have been shown to have little effect on insect calcium currents (Byerly and Leung, 1988; Hayashi and Levine, 1992). Thus, it was not surprising to find that, even at a concentration as high as $100 \mu \mathrm{M}$, both verapamil and nifedipine reduced the calcium current to some extent, but would not abolish it completely. Pearson et al. (1993) reported that $1 \mu \mathrm{M}$ verapamil reduced the calcium current in adult locust neurons by $85 \%$. This was about the maximal effect of verapamil seen in our preparation with $100 \mu \mathrm{M}$. However, we did not test any concentrations lower than that. At the same concentration, nifedipine, a dihydropyridine that is also thought to select for L-type channels in vertebrates (Tsien et al., 1988), was even less efficient.The strongest blocking effect was seen with cadmium, which completely abolished the calcium current at $50 \mu \mathrm{M}$ and significantly reduced it at concentrations well below $10 \mu \mathrm{M}$. The calcium current seems to undergo steady state inactivation at fairly negative holding potentials, being $100 \%$ available at $-100 \mathrm{mV}$ and below, about $70 \%$ available at $-70 \mathrm{mV}$, and fully inactivated at $-30 \mathrm{mV}$ and above. As is the casc with all other insect preparations studied so far, the calcium current first activates at $-40 \mathrm{mV}$ and peaks between -10 and $0 \mathrm{mV}$. Given that the partial block by $100 \mu \mathrm{M}$ verapamil and nifedipine may be a nonspecific effect, the calcium current described here has many characteristics in common with the vertebrate "N-type" calcium current, such as sensitivity to very low concentrations of cadmium, activation at relatively high voltages, and steady state inactivation at rather negative holding potentials.

It is yet unknown whether and how the above described currents are modulated, and how such a modulation may be related to neural plasticity. Indications of such have, however, emerged from studies on the Drosophila learning and memory mutants dunce $(d n c)$ and rutabaga $(r u t)$, both of which are characterized by abnormal levels in intracellular cAMP (Byers et al., 1981; Livingstone et al., 1984). A clue as to how these altered cAMP levels might cause deficient learning and memory was provided by an electrophysiological study (Zhong and Wu, 1991) which showed that in contrast to the wild type, $d n c$ larval neuromuscular junctions do not exhibit facilitation and posttetanic potentiation. As Delgado et al. (1992) demonstrated, this kind of synaptic plasticity can be restored by application of potassium channel blockers. Drosophila larval muscle fibers express a cAMP-activated potassium channel, which is persistently activated in $d n c$ (Delgado et al., 1991). In the larval muscle fibers of $d n c$, both A-current and delayed rectifier are increased, possibly as a result of elevated cAMP levels (Zhong and Wu, 1993).

Obviously, the same mechanisms underlying lack of synaptic plasticity of the $d n c$ neuromuscular junction may also be relevant in the CNS. In the brain of Drosophila, both $d n c$ and rut gene products are preferentially expressed in the intrinsic elements of the mushroom bodies, the Kenyon cells (Nighorn et al., 1991; Han et al., 1992). In the fly, however, the role of the cAMP pathway in these cells has so far not been investigated. Due to their small size $(\ll 5 \mu \mathrm{m})$ they appear to be inaccessible to electrophysiological studies in vivo. Furthermore, because of anatomical constraints, a preparation of the fly mushroom bodies and hence an isolation of their intrinsic elements does not seem feasible. The honeybee preparation described here allows selective study of this cell type, not only with electrophysiological but also with biochemical and other techniques. A potential mechanism underlying olfactory learning and memory in insects may be a change in Kenyon cell excitability through a cAMPmediated modulation of ion channels. Most of the currents described here have been shown to be modulated by cAMP in other preparations (Rudy, 1988; Tsien et al., 1988). The effect of cAMP on ion channels may be direct, or involve the activity of a cAMP-dependent kinase (PKA), an enzyme that is also found in the bee brain (Altfelder and Müller, 1991). In a biochemical assay, dopamine, noradrenaline, and octopamine have been shown to stimulate adenylyl cyclase activity in bee brain tissue, which is particularly high in the mushroom bodies (Menzel et al., 1991). With immunocytochemical techniques, dopamine- and octopamine-containing neurons were found, which project into the main input regions of the mushroom bodies, the calyces (Schäfer and Rehder, 1989; Kreissl et al., 1991). Most if not all of the octopamine immunoreactivity within the calyces could be attributed to a neuron, which in an electrophysiological study has been shown to mediate the reward in 
olfactory learning (Hammer, 1993). Furthermore, there is good evidence that acetylcholine may be transmitter of a subset of neurons conveying olfactory information from the antennal lobes to the mushroom bodies (Kreissl and Bicker, 1989). Thus, future studies will be directed toward determining the action of transmitters and neuromodulators on Kenyon cell currents, and whether CAMP is involved as a second messenger.

\section{References}

Altfelder K, Müller U (1991) Cyclic nucleotide-dependent protein kinases in the neural tissue of the honeybee Apis mellifera. Insect Biochem 21:487-494.

Baker K, Salkoff L (1990) The Drosophila shaker gene codes for a distinctive $\mathrm{K}^{+}$current in a subset of neurons. Neuron 2:129-140.

Bicker G, Menzel R (1989) Chemical codes for the control of behaviour in arthropods. Nature 337:33-39.

Byerly L, Leung H-T (1988) Ionic currents of Drosophila neurons in embryonic cultures. J Neurosci 8:4379-4393.

Byers D, Davis RL, Kiger JA (1981) Defect in cyclic AMP phosphodicsterasc due to the dunce mutation of learning in Drosophila melanogaster. Nature 289:79-81.

Christensen BN, Larmet Y, Shimahara T, Beadle D, Pichon Y (1988) Ionic currents in neurones cultured from embryonic cockroach (Periplaneta americana) brains. J Exp Biol 135:193-214.

Cook NS, Quast U (1990) Potassium channel pharmacology. In: Potassium channels (Cook NS, ed), pp 181-255. Chichester: Horwood.

Davis RL (1993) Mushroom bodies and Drosophila learning. Neuron $11: 1-14$

Delgado R, Hidalgo P, Diaz F, Latorre R, Labarca P (1991) A cyclic AMP-activated $\mathrm{K}^{+}$channel in Drosophila larval muscle is persistently activated in dunce. Proc Natl Acad Sci USA 88:557-560.

Delgado R, Latorre R, Labarca P (1992) $\mathrm{K}^{+}$channel blockers restore synaptic plasticity in the neuromuscular junction of dunce, a Drosophila learning and memory mutant. Proc R Soc Lond [Biol] 250: 181-185.

Elkins T, Ganetzky B, Wu C-F (1986) A Drosophila mutation that eliminates a $\mathrm{Ca}^{2+}$-dependent $\mathrm{K}^{+}$current. Proc Natl Acad Sci USA 83:8415-8419.

Erber J, Masuhr TH, Menzel R (1980) Localization of short-term memory in the brain of the bee Apis mellifera. Physiol Entomol 5:343358.

French AS, Sanders EJ, Duszyk E, Prasad S, Torkkeli PH, I Iashins J, Murphy RA (1993) Immunocytochemical localization of sodium channels in an insect central nervous system using a site-directed antibody. J Neurobiol 24:939-948.

Gho M, Mallart A (1986) Two distinct calcium-activated potassium currents in larval muscle fibers of Drosophila melanogaster. Pfluegers Arch 407:526-533.

Gorczyca MG, Wu C-F (1991) Single-channel $\mathrm{K}^{+}$currents in Drosophila muscle and their pharmacological block. J Membr Biol 121: 237-248.

Hamill OP, Marty A, Neher E, Sakman B, Sigworth F (1981) Improved patch-clamping techniques for high resolution current recordings from cells and cell free membrane patches. Pfluegers Arch 391:85-100.

Hammer M (1993) An identified neuron mediates the unconditioned stimulus in associative olfactory learning in honeybees. Nature 366 : 59-63.

Han P-L, Levin LR, Reed RR, Davis RL (1992) Preferential expression of the Drosophila rutabaga gene in mushroom bodies, neural centers for learning in insects. Neuron 9:619-627.

Hardie RC (1991) Voltage sensitive potassium channels in Drosophila photoreceptors. J Neurosci 11:3079-3095.

Hardie RC, Weckström M (1990) Three classes of potassium channels in large monopolar cells of the blowfly Calliphora vicina. J Comp Physiol [A] 167:723-736.

Hardie RC, Voss D, Pongs O, Laughlin SB (1991) Novel potassium channels encoded by the shaker locus in Drosophila photoreceptors. Neuron 6:477-486.

Hayashi JH, Levine RB (1992) Calcium and potassium currents in leg motoneurons during postembryonic development in the hawkmoth Manduca sexta. J Exp Biol 171:15-42.

Heisenberg M, Borst A, Wagner S, Byers D (1985) Drosophila mush- room body mutants are deficient in olfactory learning. $\mathrm{J}$ Neurogenct $2: 1-30$.

Hille B (1992) Ionic channels of excitable membranes. Sunderland, MA: Sinauer.

Kreissl S (1992) Zellbiologische und immuncytochemische Untersuchungen am zentralen Nervensystem der Honigbiene in situ und in vitro. PhD thesis, Freie Universität, Berlin.

Kreissi S, Bicker G (1989) Histochemistry of acetylcholinesterase and immunocytochemistry of an acetylcholine receptor-like antigen in the brain of the honeybee. J Comp Neurol 286:71-84.

Kreissl S, Bicker G (1992) Dissociated neurons of the pupal honeybee brain in cell culture. J Neurocytol 21:545-556.

Kreissl S, Eichmüller S, Bicker G, Rapus J, Eckert M (1991) The distribution of octopamine-like immunoreactivity in the brain of the honeybee. In: Synapse-transmission-modulation. Proceedings of the 19th Göttingen Neurobiology Conference (Elsner N, Penzlin H, eds), abstr 407. Stuttgart: Thieme.

Lapied B, Molecot O, Pelhate M (1989) Ion species involved in the electrical activity of single adult aminergic neurons isolated from the sixth abdominal ganglion of the cockroach Periplaneta americana. $\mathrm{J}$ Exp Biol 144:535-549.

Laurent G, Seymour-Laurent KJ, Johnson K (1993) Dendritic excitability and a voltage-gated calcium current in locust nonspiking local interneurons. J Neurophysiol 69:1484-1498.

Leung H-T, Byerly B (1991) Characterization of single calcium channels in Drosophila embryonic nerve and muscle cells. J Neurosci 11: 3047-3059.

Leung H-T, Branton WD, Philips HS, Jan L, Byerly L (1989) Spider toxins selectively block calcium currents in Drosophila. Neuron 3:767772.

Livingstone MS, S7iber PP, Quinn WG (1984) Loss of calcium/calmodulin responsiveness in the adenylate cyclase of rutabaga, a Drosophila learning mutant. Cell 37:205-215.

Masuhr T (1976) Lokalisation und Funktion des Kurzzcitgedächtnisses der Honigbiene, Apis mellifera L. PhD thesis, Freie Universität, Berlin.

Mauelshagen J (1993) Neural correlates of olfactory learning paradigms in an identified neuron in the honeybee brain. J Neurophysiol 69:609-625.

Menzel R, Erber J, Masuhr T (1974) Learning and memory in the honeybee. In: Experimental analysis of insect behaviour (Barton-Brown L, ed), pp 195-217. New York: Springer.

Menzel R, Wittstock S, Sugawa M (1990) Chemical codes of learning and memory in the honeybee. In: Medica hoechst, Vol 23, The biology of memory (Squire L, Lindenlaub K, eds), pp 335-359. Stuttgart: Schattauer.

Menzel R, Hammer M, Braun G, Mauelshagen J, Sugawa M (1991) Neurobiology of learning and memory in honeybees. In: The behaviour and physiology of bees (Goodman L, Fisher RC, eds), pp 323353. Oxon: $\mathrm{CAB}$ International.

Mobbs P (1982) The brain of the honeybee Apis mellifera. I. The connections and spatial organization of the mushroom bodies. Philos Trans R Soc Lond [Biol] 298:309-354.

Nighorn A, Healy MJ, Davis RL (1991) The cyclic AMP phosphodiesterase encoded by the Drosophila dunce gene is concentrated in the mushroom body neuropil. Neuron 6:455-467.

O'Dowd DK, Aldrich RW (1988) Voltage-clamp analysis of sodium channels in wild-type and mutant Drosophila neurons. J Neurosci 8:3633-3643.

Pearson HA, Lees G, Wray D (1993) Calcium channel currents in neurones from the locust (Schistocerca gregaria) thoracic ganglia. J Exp Biol 177:201-221.

Rudy B (1988) Diversity and ubiquity of K channels. Neuroscience 25:729-749.

Saito M, Wu C-F (1991) Expression of ion channels and mutational effects in giant Drosophila neurons differentiated from cell divisionarrested embryonic neuroblasts. J Neurosci 11:2135-2150.

Salkoff L (1983) Drosophila mutants reveal two components of fast transient current. Nature 302:249-251.

Salkoff L, Wyman RJ (1983) Ion currents in Drosophila flight muscle. J Physiol (Lond) 337:687-709.

Schäfer S, Rehder V (1989) Dopamine-like immunoreactivity in the brain and suboesophageal ganglion of the honeybee. J Comp Neurol 280:43-58.

Schäfer S, Rosenboom H, Menzel R (1993) Ionic currents in identified 
neurons from the mushroom body of the honeybee, Apis mellifera. In: Gene-brain-behaviour. Proceedings of the 21 st Göttingen Neurobiology Conference (Elsner N, Heisenberg M, eds), abstr 634. Stuttgart: Thieme.

Schwarz TL, Papazian DM, Carretto KC, Jan Y-N, Jan LY (1990) Immunological characterization of $\mathrm{K}^{+}$channel components from the Shaker locus and differential distribution of splicing variants in Drosophila. Neuron 2:119-127.

Singh S, Wu C-F (1989) Complete separation of four potassium currents in Drosophila. Neuron 2:1325-1329.

Singh S, Wu C-F (1990) Properties of potassium currents and their role in membrane excitability in Drosophila larval muscle fibers. J Exp Biol 152:59-76.

Solc CK, Aldrich RW (1988) Voltage-gated potassium channels in larval CNS neurons of Drosophila. J Neurosci 8:2556-2570.

Tribut F, Lapied B, Duval A, Pelhate M (1991) A neosynthesis of sodium channels is involved in the evolution of the sodium current in isolated adult DUM neurons. Pfluegers Arch 419:665-667.

Tsien RW, Lipscombe D, Madison, DV, Bley KR, Fox AP (1988) Multiple types of neuronal calcium channels and their selective modulation. Trends Neurosci 11:431-438.
Wegener JW, Tareilus E, Breer H (1992) Characterization of calciumdependent potassium channels in antennal receptor neurones of $L O$ custa migratoria. J Insect Physiol 38:237-248.

Witthöft W (1967) Absolute Anzahl und Verteilung der Zellen im Hirn der Honigbiene. Z Morphol Tiere 61:160-184.

Wu C-F, Haugland FN (1985) Voltage clamp analysis of membrane currents in larval muscle fibers of Drosophila: alteration of potassium currents in Shaker mutants. J Neurosci 5:2626-2640.

Zagotta WN, Aldrich RW (1990) Voltage-dependent gating of Shaker A-type channels in Drosophila muscle. J Gen Physiol 95:29-60.

Zagotta WN, Brainard MS, Aldrich RW (1988) Single-channel analysis of four distinct classes of potassium channels in Drosophila muscle. J Neurosci 8:4765-4779.

Zhong Y, Wu C-F (1991) Altered synaptic plasticity in Drosophila memory mutants with a defective cyclic AMP cascade. Science 251: 198-201.

Zhong Y, Wu C-F (1993) Differential modulation of potassium currents by cAMP and its long-term and short-term effects: dunce and rutabaga mutants of Drosophila. J Neurogenet, in press. 